\title{
SISTEM PENDUKUNG KEPUTUSAN UNTUK MENENTUKAN UKM/HMJ PENERIMA BANTUAN DANA TAKTIS DENGAN METODE ELECTRE DAN WEIGHTED PRODUCT
}

\author{
Ivan Novandy S, Anggraini Kusumaningrum \\ Program Studi Teknik Informatika \\ Sekolah Tinggi Teknologi Adisutjipto Yogyakarta \\ informatika@stta.ac.id
}

\begin{abstract}
Student Executive Board (SEB) is a campus organization which is an executive agency at the level of the University/Institute/College. Constraints experienced by the SEB in determining UKMHMJ tactical beneficiaries. To be able to assist in making decisions to determine UKM/HMJ beneficiaries needed a tactical decision support system (DSS). The system can use the ELECTRE method and Weighted Product method in the calculation process. The results showedthat the proposal with the highest values approaching the highest value of I(one) is the proposal of UKM/HMJ are eligible to receive financial assistance tactical.
\end{abstract}

Keywords :DSS,Tactical Fund, ELECTRE, Weighted Product.

\section{Pendahuluan}

Badan Eksekutif Mahasiswa (BEM) adalah organisasi mahasiswa intra kampus yang merupakan lembaga eksekutif di tingkat Universitas/Institut/Sekolah Tinggi. Permasalahan yang umum dihadapi oleh BEM adalah bagaimana menentukan atau memilih UKM/HMJ yang berhak menerima dana taktis. Dalam hal ini sangat diperlukan sistem yang dapat menggabungkan antara pendukung keputusan dan komputerisasi dengan menggunakan perhitungan yang tepat untuk membantu menentukan UKM/HMJ yang berhak menerima bantuan dana taktis berdasarkan kriteria atau faktor yang dijadikan pertimbangan, sehingga hasil yang didapat lebih obyektif.

Metode yang dapat diterapkan pada penelitian ini adalah metode ELECTRE dan Weighted Product. Kedua metode ini sangat cocok untuk diterapkan dalam sistem pendukung keputusan karena dengan menggunakan kedua metode yang dipakai maka hasil dari keputusan akan saling mendukung dan lebih optimal.

\section{Metodologi Penelitian}

\subsection{Analisa Sistem Pendukung Keputusan}

Pada sistem pendukung keputusan untuk menentukan UKM/HMJ penerima bantuan dana taktis yang melakukan penilaian adalah seorang presiden Bem atau seorang admin. Penilaian yang dilakukan oleh presiden BEM harus berkaitan dengan kegiatan acara. Semua kriteria yang digunakan akan memperlihatkan kualitas kegiatan secara keseluruhan. Adapun kriteria yang digunakan sebagai berikut :

1. Jenis Kegiatan.

2. Tema Kegiatan.

3. Tujuan Jangka Panjang.

4. Tujuan Jangka Pendek.

5. Manfaat Bagi Penyelenggara.

6. Manfaat Bagi Peserta.

7. Target Peserta.

8. Waktu dan Tempat. 
9. Ruang Lingkup.

10. Anggaran Biaya.

Dengan rating kecocokan pada setiap kriteria, dinilai dengan angka $1-5$, dimana setiap angka memiliki predikat tersendiri yaitu :

1. Sangat Kurang $=1$.

2. Kurang $=2$.

3. Cukup $=3$.

4. Baik $=4$.

5. Sangat Baik $=5$.

Dari setiap penilaian yang telah dilakukan oleh presiden BEM akan dihitung dengan metode ELECTRE dan Weighted Product.

\subsection{Analisa Sistem}

Sistem yang telah dibuat selanjutnya dianalisa agar penerapan teori ke dalam program dapat berjalan sesuai dengan yang diharapkan, yaitu sesuai antara perhitungan yang dilakukan secara manual dengan perhitungan yang dimasukkan kedalam program sehingga menghasilkan nilai yang tidak jauh berbeda.

\subsection{Diagram Konteks}

Diagram konteks adalah diagram tingkat atas yang hanya menggambarkan sistem secara garis besar. Merupakan diagram garis besar yang paling tidak detail dari sebuah sistem yang menggambarkan kesatuan-kesatuan luar sistem. Dapat dilihat pada gambar 1.

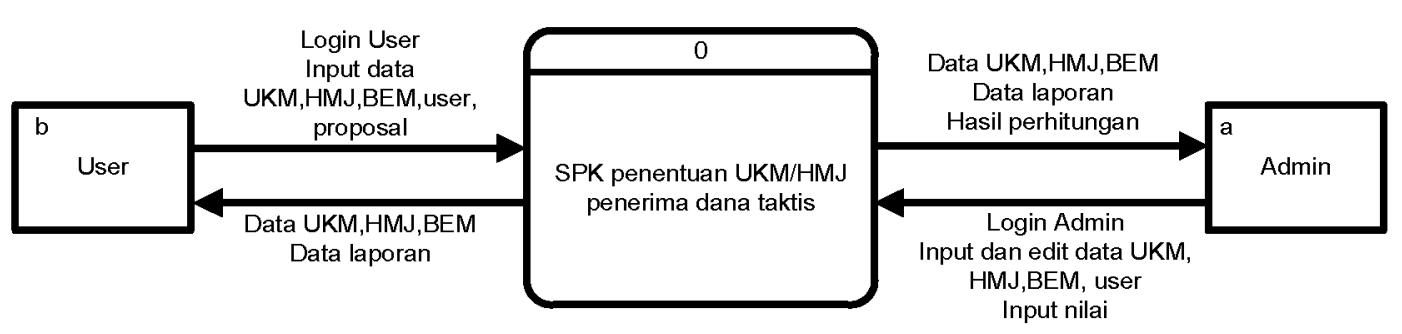

Gambar 1 Diagram Konteks

Pada gambar 1 menerangkan bahwa user melalukan login sesuai hak akses yang telah ditentukan. User dapat mendaftar untuk menjadi user baru, melalukan input dan edit data UKM, HMJ, BEM, dan proposal. Selain itu user juga dapat melihat dan mencetak data UKM, HMJ, BEM dan data laporan penerima bantuan dana taktis per-periode.

Untuk admin dapat masuk kedalam sistem dengan melakukan login sebagai admin dimana hak akses yang di dapatkan admin yaitu dapat mengupdate semua data UKM, HMJ, BEM dan user. Selain itu admin juga dapat melakukan perhitungan sistem pendukung keputusan untuk menentukan UKM/HMJ penerima bantuan dana taktis.

\subsection{DAD Level 0 Sistem Pendukung Keputusan Penentuan UKM/HMJ}

Diagram ini akan memberikan gambaran secara keseluruhan mengenai sistem, baik berupa prosesproses yang berlangsung, aliran data, penyimpanan data. 


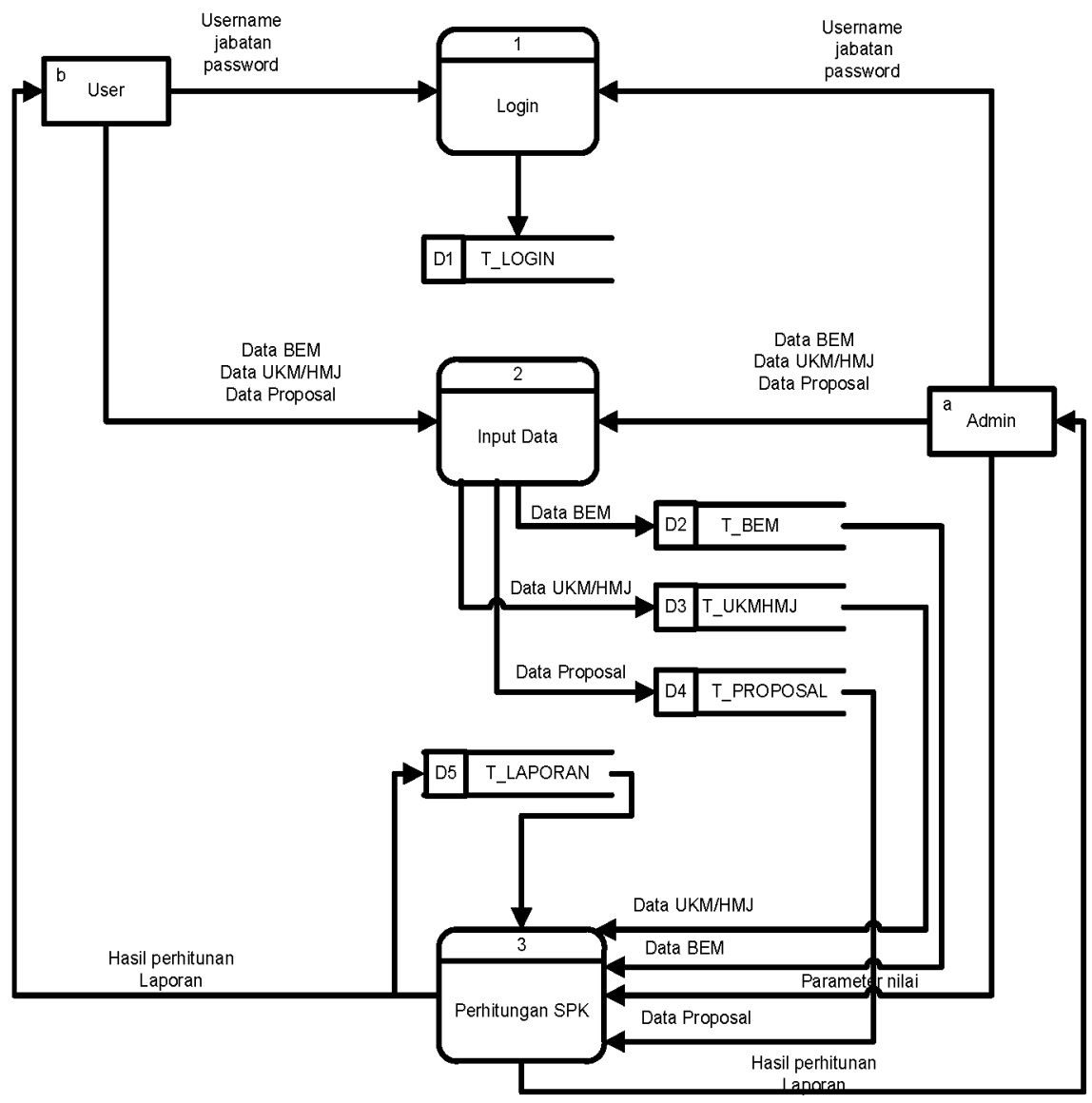

Gambar 2 DAD Level 0

Ada tiga proses dalam gambar 2 yaitu proses login, proses input data dan proses perhitungan SPK Alur data berawal dari proses login yang dilakukan oleh user untuk menginputkan data yang diperlukan dalam proses perhitungan SPK yaitu data proposal pengajuan bantuan dana taktis. Data yang telah diinputkan secara otomatis akan tersimpan dalam database yang selanjutnya akan di olah oleh admin dalam proses perhitungan SPK

\section{Hasil Dan Pembahasan}

\subsection{Implementasi Antar Muka}

Implementasi menu perhitungan SPK ini merupakan bagian utama dari sistem ini. Dimana pada tampilan ini admin akan melakukan proses perhitungan dari semua alternatif atau proposal yang sudah melalui proses verifikasi. Pada menu ini akan ditampilkan hasil dalam bentuk angka dan dalam bentuk grafik atau diagram. Tampilan menu perhitungan SPK dapat dilihat pada gambar 3. 


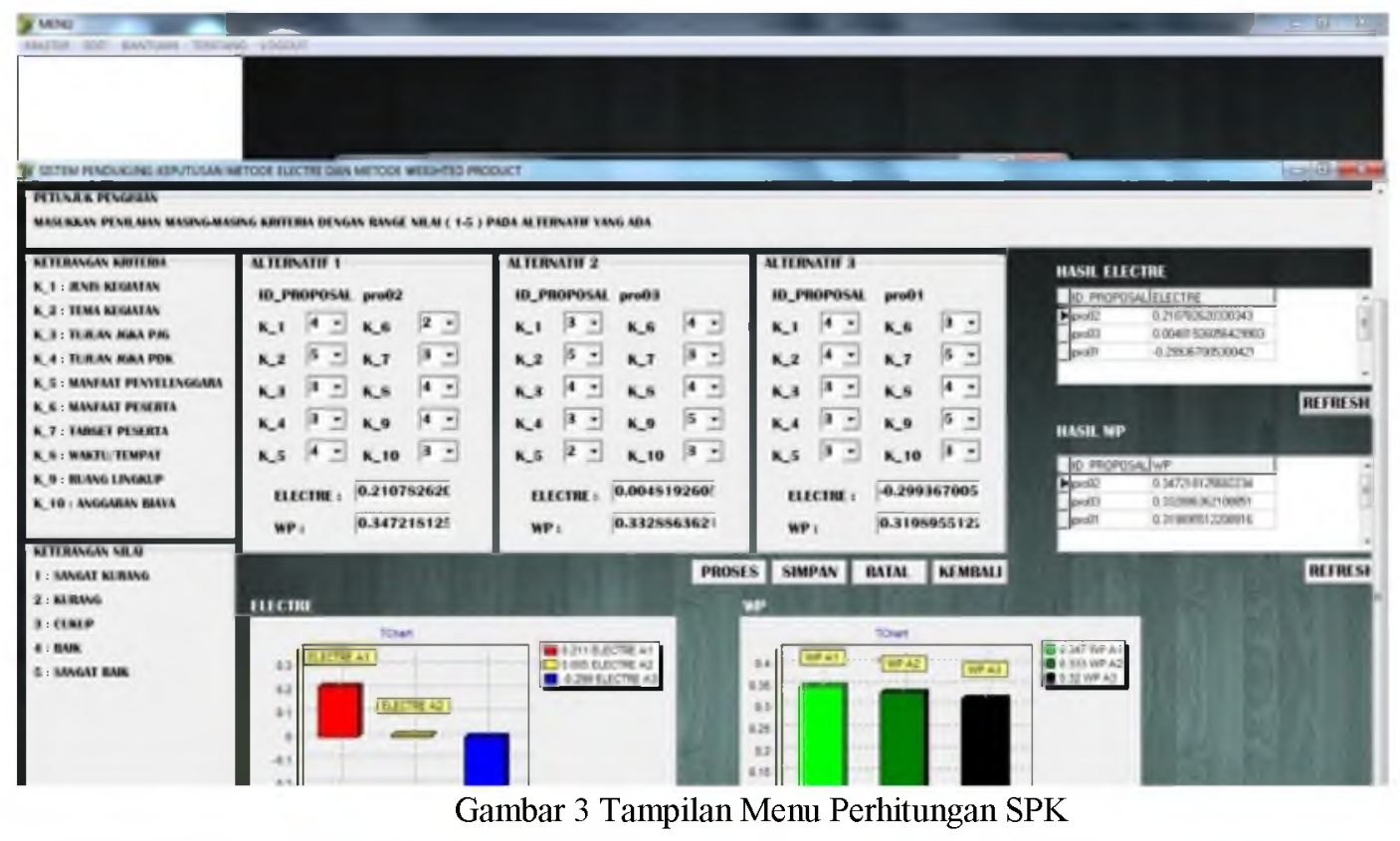

\subsection{Pembahasan}

Sistem yang telah dibuat merupakan penerapan dari teori yang ada, dibuat dalam bentuk sebuah program dengan metode perhitungan ELECTRE dan Weighted Product. Sehingga hasil yang didapatkan tidak jauh berbeda dengan perhitungan manualnya.

\subsubsection{Perhitungan ELECTRE dan Weighted Product}

Pengujian hasil perhitungan, dibuat untuk melihat perbandingan hasil perhitungan sistem dengan perhitungan manual. Tahapan Perhitungan yang diperlukan :

1. Membuat matriks keputusan dan menentukan bobot.

2. Melakukan normalisasi matriks.

3. Membuat perankingan.

\subsubsection{Penilaian Proposal UKM/HMJ}

Berikut ini adalah hasil penialian proposal oleh Presiden BEM :

Tabel 1 Hasil Penilaian Proposal oleh Presiden BEM

\begin{tabular}{|c|c|c|c|c|c|c|c|c|c|c|}
\hline & K1 & K2 & K3 & K4 & K5 & K6 & K7 & K8 & K9 & K10 \\
\hline $\begin{array}{c}\text { Pro } \\
\mathbf{0 2}\end{array}$ & Baik & $\begin{array}{c}\text { Sangat } \\
\text { baik }\end{array}$ & Cukup & Cukup & Baik & Kurang & Cukup & Baik & Baik & Cukup \\
\hline $\begin{array}{c}\text { Pro } \\
\mathbf{0 3}\end{array}$ & Cukup & $\begin{array}{c}\text { Sangat } \\
\text { baik }\end{array}$ & Baik & Cukup & Kurang & Baik & Cukup & Baik & $\begin{array}{c}\text { Sangat } \\
\text { baik }\end{array}$ & Cukup \\
\hline $\begin{array}{c}\text { Pro } \\
\mathbf{0 1}\end{array}$ & Baik & Baik & Cukup & Cukup & Cukup & Cukup & $\begin{array}{c}\text { Sangat } \\
\text { baik }\end{array}$ & Baik & $\begin{array}{c}\text { Sangat } \\
\text { baik }\end{array}$ & Cukup \\
\hline
\end{tabular}

Pada tabel 1 di tampilkan hasil penilaian proposal oleh Presiden BEM. Pada tampilan tersebut mewakili tiga proposal yang diajukan oleh UKM/HMJ. Untuk kolom pertama (alternatif) pada tabel 1 dituliskan dengan identitas proposal yang artinya adalah sebagai berikut :

1. Pro02 (Proposal no 02) : mewakili identitas proposal HMJ TF.

2. Pro03 (Proposal no 03) : mewakili identitas proposal UKM Musik.

3. Pro01 (Proposal no 01) : mewakili identitas proposal HMJ TM.

Untuk baris pertama (Kriteria) pada tabel 1 dituliskan dengan identitas kriteria yang artinya sebagai berikut :

1. K1 (Kriteria no 1) : Jenis Kegiatan. 
2. K2 (Kriteria no 2) : Tema Kegiatan.

3. K3 (Kriteria no 3) : Tujuan Jangka Panjang.

4. K4 (Kriteria no 4) : Tujuan Jangka Pendek.

5. K5 (Kriteria no 5) : Manfaat Bagi Penyelenggara.

6. K6 (Kriteria no 6) : Manfaat Bagi Peserta.

7. K7 (Kriteria no 7) : Target Peserta.

8. K8 (Kriteria no 8) : Waktu dan Tempat.

9. K9 (Kriteria no 9) : Ruang Lingkup.

10. K10 (Kriteria no 10): Anggaran Biaya.

Berikut ini adalah hasil pemberian bobot preferensi oleh Presiden Bem, pada Tabel 2 menjelaskan bobot preferensi yang di tentukan oleh Presiden BEM.

Tabel 2 Bobot preferensi penilaian Presiden BEM

\begin{tabular}{|c|c|c|c|c|c|c|c|c|c|c|}
\hline Kriteria & K1 & K2 & K3 & K4 & K5 & K6 & K7 & K8 & K9 & K10 \\
\hline $\begin{array}{c}\text { Bobot } \\
\text { Kriteria }\end{array}$ & Cukup & $\begin{array}{c}\text { Tidak } \\
\text { penting }\end{array}$ & $\begin{array}{c}\text { Kurang } \\
\text { penting }\end{array}$ & $\begin{array}{c}\text { Kurang } \\
\text { penting }\end{array}$ & Cukup & Cukup & Cukup & $\begin{array}{c}\text { Kurang } \\
\text { penting }\end{array}$ & Penting & $\begin{array}{c}\text { Sangat } \\
\text { penting }\end{array}$ \\
\hline
\end{tabular}

\subsubsection{Perbandingan Hasil Perhitungan Manual Presiden BEM dengan SPK}

Pada perbandingan hasil ini, data yang digunakan adalah data perhitungan pada tahun periode 2011/2012. Data tersebut dapat dilihat pada tabel 3.

Tabel 3 Hasil Penilaian Proposal Manual dari BEM

\begin{tabular}{|c|c|c|}
\hline Kode Proposal & Hasil Penjumlahan Dari Nilai Kriteria & Nilai Akhir $(\mathbf{P i} / \Sigma$ Pi) \\
\hline Pro01 & 3 & 0,19 \\
\hline Pro02 & 7 & 0,44 \\
\hline Pro03 & 6 & 0,37 \\
\hline
\end{tabular}

Dari tabel 3 dapat diketahui bahwa pada proses perhitungan manual yang dilakukan oleh BEM menunjukkan Pro02 memperoleh nilai akhir tertinggi diantara proposal yang lainnya yaitu dengan nilai akhir 0,44. Maka pada penilaian manual yang dilakukan oleh BEM di dapatkan hasil Pro02 yang akan mendapatkan dana taktis dikarenakan memperoleh nilai tertinggi dan paling mendekati nilai tertinggi yaitu 1.Untuk data hasil penilaian yang didapat dari perhitungan sistem dapat dilihat pada tabel 4 .

Tabel 4 Hasil Penilaian Proposal Menggunakan Sistem

\begin{tabular}{|c|c|c|}
\hline \multirow{2}{*}{ Kode Proposal } & \multicolumn{2}{|c|}{ Hasil Penilaian Sistem } \\
\cline { 2 - 3 } & Metode ELECTRE & Metode WP \\
\hline Pro01 & $-0,3$ & 0,32 \\
\hline Pro02 & 0,2 & 0,34 \\
\hline Pro03 & 0,005 & 0,33 \\
\hline
\end{tabular}

Pada tabel 4 dapat diketahui bahwa pada proses perhitungan pada sistem menunjukkan Pro02 memperoleh nilai akhir tertinggi diantara proposal yang lainnya yaitu dengan nilai akhir pada metode ELECTRE yaitu 0,2 dan pada metode Weighted Product memperoleh nilai 0,34. Maka pada penilaian sistem di dapatkan hasil Pro02 yang akan mendapatkan dana taktis dikarenakan memperoleh nilai tertinggi dan paling mendekati nilai tertinggi yaitu 1 .

Dari kedua tabel diatas maka dapat kita bandingkan antara hasil penilaian manual yang dilakukan oleh BEM dan dengan penilaian yang dilakukan oleh sistem yang telah dibuat untuk mengetahui apakah hasil yang didapatkan sama atau tidak. Data hasil perbandingan dapat dilihat pada tabel 5 . 
Tabel 5 Perbandingan Hasil Perhitungan Manual Presiden BEM Dengan SPK

\begin{tabular}{|c|r|r|r|}
\hline \multirow{2}{*}{ Kode Proposal } & \multicolumn{3}{|c|}{ HASIL PERHITUNGAN } \\
\cline { 2 - 4 } & Manual BEM & $\begin{array}{c}\text { SPK } \\
\text { (ELECTRE) }\end{array}$ & SPK (WP) \\
\hline Pro01 & 0,19 & $-0,3$ & 0,32 \\
\hline Pro02 & 0,44 & 0,2 & 0,34 \\
\hline Pro03 & 0,37 & 0,005 & 0,33 \\
\hline
\end{tabular}

Pada tabel 5 menjelaskan hasil perbandingan perhitungan dari proposal yang masuk pada saat itu. Dari hasil tersebut dapat diketahui perbandingan perhitungan dari presiden BEM dan perhitungan menggunakan SPK. Hasil yang didapatkan dari perhitungan manual BEM menunjukkan Pro02 memperoleh hasil tertinggi yaitu 0,44 dan dari perhitungan SPK dengan Metode ELECTRE menunjukan Pro02 memperoleh hasil tertinggi yaitu 0,2 dan dari perhitungan SPK dengan menggunakan Metode Weighted Product menunjukan Pro02 juga memperoleh hasil tertinggi yaitu 0,34 dengan mengacu pada nilai yang paling mendekati nilai tertinggi yaitu 1 .

Maka dari data yang telah dihitung menjelaskan bahwa perhitungan menggunakan SPK menunjukan proposal dengan nilai terbesar yang sama dengan penilaian manual yang dilakukan oleh BEM yaitu Pro02. Dengan masing-masing nilai dari setiap perhitungan. Sehingga sistem ini dapat membantu BEM untuk menentukan UKM/HMJ penerima bantuan dana taktis dengan hasil perhitungan yang sama.

\section{Penutup}

\subsection{Kesimpulan}

1. Sistem pendukung keputusan untuk menentukan UKM/HMJ penerima bantuan dana taktis merupakan solusi bagi BEM dalam menentukan UKM/HMJ penerima bantuan dana taktis.

2. Metode Electre dan Weighted Product dapat diterapkan dalam sistem pendukung keputusan untuk menentukan UKM/HMJ penerima bantuan dana taktis dan menghasilkan nilai yang sama antara perhitungan manual BEM dan sistem.

\subsection{Saran}

1. Sistem ini dapat dikembangkan lagi menjadi sistem yang bersifat client server sehinga dapat dieksekusi oleh banyak user.

2. Sistem ini dapat dikembangkan lagi dengan perhitungan yang lainnya misalnya Metode Topsis, SAW, dan AHP.

3. Sistem ini dapat dikembangkan dengan menjadi sistem berbasis WEB untuk memudahkan dalam menyampaikan informasi dan melakukan proses pengajuan proposal bagi UKM/HMJ

\section{Daftar Pustaka}

Jogiyanto, HM, 2005, Analisis dan Desain Sistem Informasi: Pendekatan Terstruktur Teori Dan Praktik Aplikasi Bisnis. Andi. Yogyakarta

Kadir, Abdul, 2005, Pemrograman Database dengan delphi 7 menggunakan Acces dan ADO. Andi Offset. Yogyakarta

Kusrini, 2007, Konsep dan Aplikasi Sistem Pendukung Keputusan. Penerbit Andi. Yogyakarta

Kusumadewi, Sri., Hartati, S., Harjoko, A., dan Wardoyo, R, 2006, Fuzzy Multi-Attribute Decision Making (FUZZY MADM). Graha Ilmu. Yogyakarta

Nugroho, Bunafit, 2005, Database Relational dengan MySQL. Andi Offset. Yogyakarta.

Shofwatul, Uyun, 2011, A Fuzzy Topsis Multiple-Attribute Decision Making for Scholarship Selection.Jurnal TELEKOMUNIKA, Vol.9, No.1, pp.37-46. 
Turban E., Aronson J.E., dkk, 2003, Decision Support Systems and Intelligent Systems ( Sistem Pendukung Keputusan dan Sistem Cerdas). Andi Offset. Yogyakarta

Wardoyo, R., Hartati, S. \& Harjoko, A., 2012, ELECTRE-Entropy method inGroup Decision Support System Modelto Gene Mutation Detection. International Journal of Advanced Research in Artificial Intelligence (IJARAI), Vol.1, No.1, pp. 58-63.

Wolfgang, J., Bernroider, E, 2005, Multi-Criteria Decision Making An Application Study of ELECTRE \& TOPSIS. dalam Fuzzy Multi-Attribute Decision Making (FUZZY MADM). Graha Ilmu. Yogyakarta 
Ivan Novandy S, Anggraini Kusumaningrum 